ENTREPRENEURSHIP AND SUSTAINABILITY ISSUES

ISSN 2345-0282 (online) http://jssidoi.org/jesi/

2021 Volume 8 Number 3 (March)

http://doi.org/10.9770/jesi.2021.8.3(42)

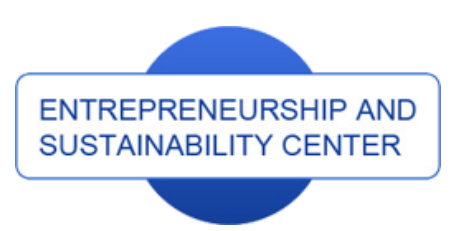

Publisher

$\underline{\text { http://jssidoi.org/esc/home }}$
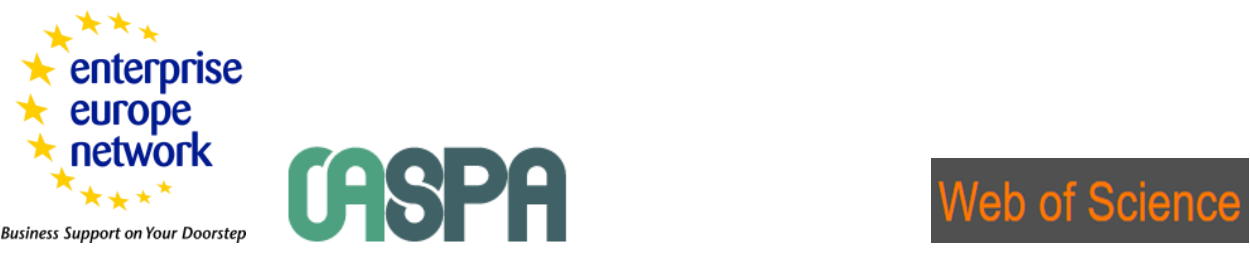

\title{
HOW WE CAN BENEFIT FROM PERSONAL FINANCE MANAGEMENT APPLICATIONS DURING THE COVID-19 PANDEMIC? THE POLISH CASE
}

\author{
Krzysztof Waliszewski ${ }^{1}$, Anna Warchlewska ${ }^{2}$ \\ Poznan University of Economics and Business, Al. Niepodległości 10, 61-875 Poznań, Poland \\ E-mails: ${ }^{1}$ krzysztof.waliszewski@ue.poznan.pl; ${ }^{2}$ anna.warchlewska@ue.poznan.pl
}

Received 15 November 2020; accepted 14 February 2021; published 30 March 2021

\begin{abstract}
The aim of this article is to determine if and to what extent sociodemographic factors are related to how home budget management applications are evaluated. The authors attempted to verify to what extent applications supporting personal finance management are beneficial and popular in Poland via a CAWI online survey. The architecture of the research covered the following areas: the name of the application used, its method of use, the level of complexity of the software installation process, evaluation of the application's transparency, intuitiveness, functionality, if it meets financial needs, the technical and substantive faults of the application, degree of satisfaction with the application as well as recommendations for further development, the advantages and disadvantages of the application, the use of PFM during the SARS-CoV-2 era. The study showed that users tend to use non-banking applications more often than financial managers offered by banks. A PFM benefit analysis shows that the applications are highly transparent, structured, intuitive and that the respondents have positive approach towards using them. The SARS-CoV-2 pandemic has given grounds to finding gaps in remote customer service, such as better adaptation to the needs of current settlements and payments, the incapability to scan documents, and the lack of advice and ongoing contact with a consultant.
\end{abstract}

Keywords: modern financial technologies; Personal Finance Management; FinTech; pandemic SARS-CoV-2

Reference to this paper should be made as follows: Waliszewski, K., Warchlewska, A. 2021. How we can benefit from personal finance management applications during the Covid-19 pandemic? The Polish Case. Entrepreneurship and Sustainability Issues, 8(3), 681-699. http://doi.org/10.9770/jesi.2021.8.3(42)

JEL Classification: D12; G41; G53; O33

\footnotetext{
* The project was financed within the Regional Initiative for Excellence programme of the Minister of Science and Higher Education of Poland, years 2019-2022, grant no. 004/RID/2018/19, financing 3,000,000 PLN.
} 


\section{ENTREPRENEURSHIP AND SUSTAINABILITY ISSUES}

ISSN 2345-0282 (online) http://jssidoi.org/jesi/

2021 Volume 8 Number 3 (March)

http://doi.org/10.9770/jesi.2021.8.3(42)

Make your research more visible, join the Twitter account of ENTREPRENEURSHIP AND SUSTAINABILITY ISSUES: @Entrepr69728810

\section{Introduction}

The growing popularity of mobile applications forces the banking sector to look at the market more broadly and to cooperate with the FinTech industry. In order to be able to compete with external entities for the user of their applications, banks must implement more advanced personalisation strategies to facilitate more targeted marketing and product development using artificial intelligence (Alt et al. 2018; Nicoll 2019).

The effectiveness of using artificial intelligence (Belanche et al. 2018) in various aspects of the economy has been a topic of discussion for many years now. The speed with which users implement and adapt new technological solutions depends on the level of sophistication offered by financial services in a given country. Each financial institution struggles with data overload and the problem of processing and selecting the most relevant. Thanks to technology, robotisation and artificial intelligence, it becomes possible to personalise customer service and switch to remote service channels. The application of modern financial solutions not only serves to minimise the costs associated with employment, but also to target action on the complex problems faced by customers (Javaria et al., 2020). Robotics and artificial intelligence (Xie, 2019) both significantly influence the financial industry, as the technology used there is a key element in the strategy of banks and emerging financial entities (Baker \& Dellaert 2017; Jung et al. 2018). Replacing traditional consultancy services with innovations, especially at the beginning, is not met with much enthusiasm, mainly due to the novelty factor, competition, fear and lack of knowledge (Belanche at al. 2019).

Improvements in the management of home finances can be made using appropriate tools. The desire to use modern solutions is associated with the need to choose the right software, purchase a license or install applications on a mobile device. The form of using PFM tools depends on the consumer's preferences and/or the form of making them available to the users offered by the provider. Combination of advances in technology, new uses of data, and changes in customer preferences and expectations are likely to create lasting structural changes in financial services (Xiao, Tao, 2020) like credit, digital payments, savings, investments \& PFM, distributed ledger technology) (Marder 2016).

The key impetus behind the development of solutions based on traditional banking services is the PSD2 directive. Opening up financial institutions to third parties may provide a basis for building new solutions and business strategies, mainly in order to offer clients innovative solutions (EU Directive 2015/2366). Implementation of the PSD2 (Payment Services Directive 2) directive enables financial data to be imported and exported from clients' accounts at various banks and to register financial transactions, group, aggregate and visualise financial events (Gafrikova, Szczesny, Odrzygóźdź, 2015). One of the regulatory challenges in terms of sensitive data processing is the outsourcing of critical functions. The use of cloud solutions may adversely affect the sense that one has control over the personal data of the entities that commission the creation, implementation and service of, inter alia, PFM applications to third parties. It is important to maintain a sense of control over the data and to ensure the effective removal of data from the cloud at the end of a contractual period (EIOPA-BoS-20-002).

Bearing in mind the growing importance of modern financial technologies and entrenched social isolation, entailing the need to remotely manage the home budget during the SARS-CoV-2 pandemic, the study undertook an analysis of the functionality, attitudes and expectations of polish customers regarding the use of financial applications. The aim of this article is to determine if and to what extent sociodemographic factors are related to the how home budget management applications are evaluated. In order to achieve this research goal, a nationwide CAWI online survey was carried out in the period from 01/08/2020 to 30/09/2020 and 301 statistically significant responses were obtained. The architecture of the research covered the following areas: (a) the name of the 


\section{ENTREPRENEURSHIP AND SUSTAINABILITY ISSUES}

ISSN 2345-0282 (online) http://jssidoi.org/jesi/

2021 Volume 8 Number 3 (March)

http://doi.org/10.9770/jesi.2021.8.3(42)

Make your research more visible, join the Twitter account of ENTREPRENEURSHIP AND SUSTAINABILITY ISSUES: @Entrepr69728810

application used, (b) its method of use, (c) the level of complexity of the software installation process, (d) evaluation of the application's transparency, (e) intuitiveness, (f) functionality, (g ) meeting financial needs, (h) the technical and substantive flaws in the application, (i) degree of satisfaction with the application and recommendations, (j) advantages and disadvantages of the application, (k) use of PFM in the times of SARSCoV-2.

\section{Theoretical background}

Digital technologies are increasingly integrated in the economy and making a significant impact in the financial industry by introducing new products, services and providers. Digitalisation is affecting individuals and businesses globally, with mobile money services now available in 64\% of developing countries (GSMA 2019), and their spread is likely to increase hand in hand with the growing penetration rate of mobile connections. These changes increase the demand for financial education, financial consumer protection and financial inclusion policies (OECD 2018, Abad-Segura et al. 2020).

Customer self-services enables a new service model to be created that bases its assumptions on the equal involvement of investors and bidders in the financial management process and can influence the establishment of long-term relationships between the parties involved (Djelassi et al. 2018). Most financial institutions do not take advantage of customer self-service potential because they base their assumptions on an incomplete business model in the area of remote service. Remote financial management support services are focused on the speed of response to reported needs, reducing service time, convenience for customers and lowering costs for the service provider (Boon-itt 2015). Innovation in finance may go hand in hand with consumer discomfort arising from lack of control over modern tools, uncertainty of their knowledge and skills, lack of confidence in technology and a sense of technological overwhelm (Parasurman 2000).

The shift in consumer preferences and online activity results mainly from forced, social isolation. The lack of data on the distribution of popularity of financial applications offered by third parties and banks does not allow us to conclude whether the increasing popularity of applications may have an impact on the evolution of banks' business models. Moreover, the uncertainty of the fintech market is growing. Fintech (or lendtech) companies, which offer assistance in automating contract signing procedures and optimising internal processes, are also likely to survive post-crisis. Traditional loan and wealth management companies may find themselves much more turbulent water, as demand for such services is in decline (Blue Media 2020; Fintek 2020).

Significantly, the innovation market is currently passing through regulatory sandboxes. It should be realised that financial technological innovations are just the beginning of creating products or services that require effective regulatory adjustments through the use of artificial intelligence, distributed ledger technology, blockchain or big data analysis and processing. To this end, test programs ('regulatory sandboxes') enable products and services to be tested in a controlled environment, strive to speed up the process of product introduction (with potentially lower costs), support security in the area of consumer protection and boost opportunities to access financing for innovation (Financial Conduct Authority 2020).

The Basel Committee on Banking Supervision categorised innovation in technology (Thakor 2019). The development of the FinTech industry affects the four major areas of financial services: credit and savings, payment and settlement, investment, and insurance, which are all components of the financial planning process (Waliszewski 2014). The PFM application market is divided into applications offered by financial institutions from the banking sector and applications offered by external entities (non-banking, community). Mobile 


\section{ENTREPRENEURSHIP AND SUSTAINABILITY ISSUES}

ISSN 2345-0282 (online) http://jssidoi.org/jesi/

2021 Volume 8 Number 3 (March)

http://doi.org/10.9770/jesi.2021.8.3(42)

Make your research more visible, join the Twitter account of ENTREPRENEURSHIP AND SUSTAINABILITY ISSUES: @Entrepr69728810

applications on the global markets that help to manage personal finances are especially aimed at the young generation that is entering adulthood. They are characterised by a modern approach in terms of graphics, functionality and availability for smartphones of different generations. It should be noted that developers of available applications on the market compete with each other in terms of usefulness of their programs and their functionality. They are undoubtedly connected by a practical dimension, which in the case of the subject of finance is extremely important. The financial sector is facing the changes that result from technological developments (Omarini 2018). The implementation of advanced IT systems, business events and data collection and processing is an opportunity for the banking industry to improve profitability and customer relations. Cooperation on the use of PFM from the worlds of business and science is also essential, as demonstrated by research already carried out in this area (Table 1). Research activities have been intensifying since 2012, both in the field of cognitive consumer behaviour and the tools used to support the process of personal finance management.

The literature on the subject defines the criteria for assessing the quality of financial applications (mobile and websites). The most important areas include: reliability, usability and functionality. Functionality is understood as the availability of a function that can be measured by means of defined requirements, the capability to interact with other systems, the maintenance of security standards and accuracy of results achieved. Reliability is the capability of a website or application to operate efficiently under certain conditions. Among others, this is characterised by tolerance of errors, the site's ability to return to normal operation, and the frequency of failures.

Table 1. Selected research on PFM in Poland and worldwide

\begin{tabular}{|c|c|c|c|}
\hline Year & $\begin{array}{l}\text { Author of the } \\
\text { study/report }\end{array}$ & Subject of the study & Main conclusions of the study \\
\hline 2009 & $\begin{array}{l}\text { F. Philip, M. James, E. } \\
\text { Joorgen; Cisco Internet } \\
\text { Business Solution } \\
\text { Group (IBSG) }\end{array}$ & $\begin{array}{l}\text { Financial priorities } \\
\text { for banking services } \\
\text { and preferred forms } \\
\text { of customer contact } \\
\text { with the bank }\end{array}$ & $\begin{array}{l}\text { Financially active consumers and those using PFM applications rarely } \\
\text { migrate from bank to bank. They have higher bank account balances and } \\
\text { use a wider range of products and services. }\end{array}$ \\
\hline 2012 & $\begin{array}{l}\text { Employee Benefit } \\
\text { Research Institute and } \\
\text { Mathew Greenwald } \\
\text { \&Associates, } \\
\text { Inc.Retirement }\end{array}$ & $\begin{array}{l}\text { How do consumers } \\
\text { manage } \\
\text { finances their } \\
\text { (convenience } \\
\text { analysis) }\end{array}$ & $\begin{array}{l}\text { Only a small proportion of consumers of working age and post-working } \\
\text { age have a positive view of the use of Internet technologies to manage } \\
\text { their finances. Among active website users: } 4 \text { out of } 10 \text { employees and } 1 / 3 \\
\text { of retired people declared that they feel very good about keeping accounts } \\
\text { through online calculators. Less interest is observed in the area of online } \\
\text { specialist advice. }\end{array}$ \\
\hline 2012 & $\begin{array}{l}\text { M. Musiał } \\
\text { University of Szczecin }\end{array}$ & $\begin{array}{l}\text { To what extent do } \\
\text { Polish households } \\
\text { use basic personal } \\
\text { finance management } \\
\text { tools? (creating a } \\
\text { household budget) }\end{array}$ & $\begin{array}{l}\text { Polish households use personal finance management tools to a small } \\
\text { extent. However, the most popular tool is the household budget prepared } \\
\text { in the traditional form (card and paper). The relationship between the use } \\
\text { of personal finance management tools and education was indicated (the } \\
\text { percentage of people using these tools increases with the level of } \\
\text { education). }\end{array}$ \\
\hline 2013 & $\begin{array}{l}\text { Javelin Strategy \& } \\
\text { Research }\end{array}$ & $\begin{array}{l}\text { Research on } \\
\text { consumer } \\
\text { expectations of }\end{array}$ & $\begin{array}{l}\text { Respondents in } 56 \% \text { declared that they would be willing to use PFM tools } \\
\text { in their basic account. The use of remote tools will have an impact on the } \\
\text { constant supervision of the budget, allow for forecasting and planning. } \\
\text { American consumers declared that they would like to be able to aggregate } \\
\text { all financial data in one application. Banks should focus their attention on } \\
\text { personalization of advice, alerts. }\end{array}$ \\
\hline
\end{tabular}


ENTREPRENEURSHIP AND SUSTAINABILITY ISSUES

ISSN 2345-0282 (online) http://jssidoi.org/jesi/

2021 Volume 8 Number 3 (March)

http://doi.org/10.9770/jesi.2021.8.3(42)

Make your research more visible, join the Twitter account of ENTREPRENEURSHIP AND SUSTAINABILITY ISSUES: @Entrepr69728810

\begin{tabular}{|c|c|c|c|}
\hline 2013 & $\begin{array}{l}\text { A. Barembruch } \\
\text { University of Gdansk }\end{array}$ & $\begin{array}{l}\text { Differences between } \\
\text { classic and modern } \\
\text { personal finance } \\
\text { management tools. } \\
\text { Disadvantages and } \\
\text { advantages of PFM. }\end{array}$ & $\begin{array}{l}\text { The competitive advantage of banks which already implement PFM } \\
\text { systems in Poland as part of online banking may be undermined when the } \\
\text { services offered within a given bank will only concern products offered } \\
\text { within that bank. }\end{array}$ \\
\hline 2016 & $\begin{array}{l}\text { M. Heikel-Elsabeh, S. } \\
\text { Nouet, M. Nayaradou }\end{array}$ & $\begin{array}{l}\text { Use and application } \\
\text { of PFM applications } \\
\text { for personal and } \\
\text { corporate finance } \\
\text { management. }\end{array}$ & $\begin{array}{l}\text { The use of PFM applications depends on the purpose and application of } \\
\text { the tools. Consumers who use mobile solutions more intensively prefer to } \\
\text { use applications offered by external entities instead of banking } \\
\text { applications. Users emphasise the complexity of non-banking tools. }\end{array}$ \\
\hline 2017 & $\begin{array}{l}\text { Chamber of Electronic } \\
\text { Economy/Mobile } \\
\text { Institute }\end{array}$ & $\begin{array}{l}\text { Pole's wallet: } \\
\text { Analysis of } \\
\text { expenditure and } \\
\text { payment methods }\end{array}$ & $\begin{array}{l}\text { The use of banking services was declared by } 80 \% \text { of Internet users, of } \\
\text { which } 28 \% \text { use the classic bank account management channel, } 36 \% \\
\text { choose the Internet service, } 36 \% \text { choose the bank's mobile service. The } \\
\text { Polish consumer presents himself as a pragmatic and open to innovation } \\
\text { financial market participant. }\end{array}$ \\
\hline $\begin{array}{l}2017- \\
2018\end{array}$ & $\begin{array}{l}\text { A. Samsel } \\
\text { University of Szczecin }\end{array}$ & $\begin{array}{l}\text { Personal finance } \\
\text { planning. } \\
\text { Information obtained } \\
\text { from households. }\end{array}$ & $\begin{array}{l}\text { Households do not run the household budget for the most part (they do not } \\
\text { manage their income in a planned manner). Households (head of } \\
\text { household) have declared that they have their budget under control and do } \\
\text { not have to plan regularly. Moreover, according to the respondents, } \\
\text { managing the budget takes time - this is a disincentive. }\end{array}$ \\
\hline 2018 & Aite Group & $\begin{array}{l}\text { Construction/reconst } \\
\text { ruction of personal } \\
\text { finance management. } \\
\text { Tasks for banks. }\end{array}$ & $\begin{array}{l}\text { About } 75 \% \text { of respondents aged } 22-49 \text { indicate that they are interested in } \\
\text { using a virtual financial coach. An opportunity for banks is to use artificial } \\
\text { intelligence to provide tools to support the financial management process. } \\
\text { Banks should strive to implement an interactive tool that will help } \\
\text { consumers take control of their financial condition. }\end{array}$ \\
\hline 2020 & $\begin{array}{l}\text { Waliszewski } \\
\text { Krzysztof, } \\
\text { Warchlewska Anna } \\
\text { Poznan Univeristy of } \\
\text { Economics and } \\
\text { Business }\end{array}$ & $\begin{array}{l}\text { Personal Finance } \\
\text { Management } \\
\text { (student's point of } \\
\text { view), }\end{array}$ & $\begin{array}{l}\text { The results of a survey conducted among students of the University of } \\
\text { Economics in Poznan indicate that financial applications offered by } \\
\text { institutions that are not banks are extremely popular. In addition, the } \\
\text { pandemic period highlighted technical and substantive gaps in } \\
\text { applications such as the need to update functionality regarding remote } \\
\text { contact with the user for ongoing settlements and payments, advice and } \\
\text { ongoing contact with a consultant and remote assistance in formalities } \\
\text { concerning loans and deposits. According to the respondents, PFM } \\
\text { applications support the process of financial management and saving } \\
\text { money, which they found valuable in terms of enhancing economic and } \\
\text { financial knowledge as well as financial skills. } \\
\text { Within the scope of the first robo-advice user survey in Poland, it should } \\
\text { be indicated that the type of investment strategy used, the ethicality } \\
\text { evaluation, development prospects, and opinions on robo-advice are } \\
\text { viewed positively and investors are satisfied with robo-advice. }\end{array}$ \\
\hline
\end{tabular}

Source: Own elaboration based on: Farah, Macaulay, Ericsson 2010; Uryniuk 2012; RCS 2012; Musiał 2015, aleBank.pl 2013, Barembruch 2013; Haikel-Elsabeh, Nouet 2016; eIzby Report 2017; Samsel 2019; Albertazzi 2018, Waliszewski \& Warchlewska, 2020a and 2020b.

Usability, on the other hand, is understood as the accuracy of the user interface construction, which is based on efficiency, satisfaction, rememberability, resistance to errors and speed of learning (Nielsen 2012). Examples of non-banking applications are presented in table 2. 


\section{ENTREPRENEURSHIP AND SUSTAINABILITY ISSUES}

ISSN 2345-0282 (online) http://jssidoi.org/jesi/

2021 Volume 8 Number 3 (March)

http://doi.org/10.9770/jesi.2021.8.3(42)

Make your research more visible, join the Twitter account of ENTREPRENEURSHIP AND SUSTAINABILITY ISSUES: @ Entrepr69728810

Table 2. Selected non-banking PFM

\begin{tabular}{|l|l|}
\hline $\begin{array}{l}\text { Non-banking } \\
\text { applications }\end{array}$ & $\begin{array}{l}\text { You Need a Budget, Kontomierz, Money Lover, Kwitki, Wallet, Fuelio, Billy, Mój protfel - MyMoneyTracek, Pan } \\
\text { Paragon, Szybki Budżet, Mint, Quicken, Robinhood, Prism, Spendee, Monefy, Personal Capital, Birch Finance } \\
\text { Acorns, Twine, Bilo, BillTech, BillBook, Cashap, Comperia.pl, Comapre King.pl, Goodie, Google Pay, Apple } \\
\text { Pay, Samsung Pay, Xoom, Circle Pay, Venmo, Square Cash, Zelle, Facebook Messenger, Nice Pay, Kekemeke, } \\
\text { Lepsza Oferta.pl, Peyt, Strands, Kalkulator spalania paliwa, Guilt - Expense Manager, Garmin Pay, Skarbnik, } \\
\text { Monefy- Menedżer finansowy, ShuCash, ePortfel, PNC Virtaul Wallet, My Portfolio, Cashcontrol.pl, Figgy.pl, } \\
\text { ifin.pl, Tu cuentas, Money Manager, Mis Finanzas, Eazzy Banking, iFIN24, fin4Family, Moneyspire, } \\
\text { Moneydance, moneyZOOM, wxBanker, payZZER, Ace Money Receipts, Microsoft Money }\end{array}$ \\
\hline $\begin{array}{l}\text { Non-banking } \\
\text { applications (in } \\
\text { social media) }\end{array}$ & $\begin{array}{l}\text { Bank blogging, microblogging, bank Internet fora, wiki websites, crowdsourcing, Web syndication, podcasting, } \\
\text { Web widgets, folksonomy and tag clouds, social bookmarking, social media services (Facebook, Youtube banking) }\end{array}$ \\
\hline
\end{tabular}

Source: own elaboration.

Polish consumers of financial services are very interested in using solutions typical for open banking (a characteristic feature of open banking is transparency in access to financial data and freedom to manage them), $48 \%$ of them would like to use an application that allows them to manage accounts in different banks, and $25 \%$ of them would like to use an application that allows them to plan their expenses based on transaction history from different sources. Moreover, 24\% of respondents would like to use financial services that offer far-reaching personalisation, based on data from their accounts in different institutions. As the number of financial service providers increases, cooperation between different financial entities is essential.

According to the Mastercard survey (Mastercard 2020) on digital banking - European Digital Banking Survey, May 2019 - 94\% of Poles surveyed believe that such partnerships are an immanent element for creating innovations in finance, and $26 \%$ believe that this cooperation will intensify in the future. Mastercard has been supporting the process of digitisation of the financial sector and cooperation between large institutions and the FinTech sector for years. The market of applications ${ }^{\dagger}$ supporting the process of personal finance management is surging, especially on the Polish market, as evidenced by the awards for IKO PKO Bank Polski S.A. for the best banking application in the world appreciated by the British service Retail Banker International. The PeoPay application of Bank Pekao S.A. was recognised in 2018 in the EFMA Accenture Distribution \& Marketing contest for the best innovation in the world.

\footnotetext{
$\dagger$ The analysis of selected applications was based on websites and applications of SWF services.
} 
ENTREPRENEURSHIP AND SUSTAINABILITY ISSUES

ISSN 2345-0282 (online) http://jssidoi.org/jesi/

2021 Volume 8 Number 3 (March)

http://doi.org/10.9770/jesi.2021.8.3(42)

Make your research more visible, join the Twitter account of ENTREPRENEURSHIP AND SUSTAINABILITY ISSUES: @Entrepr69728810

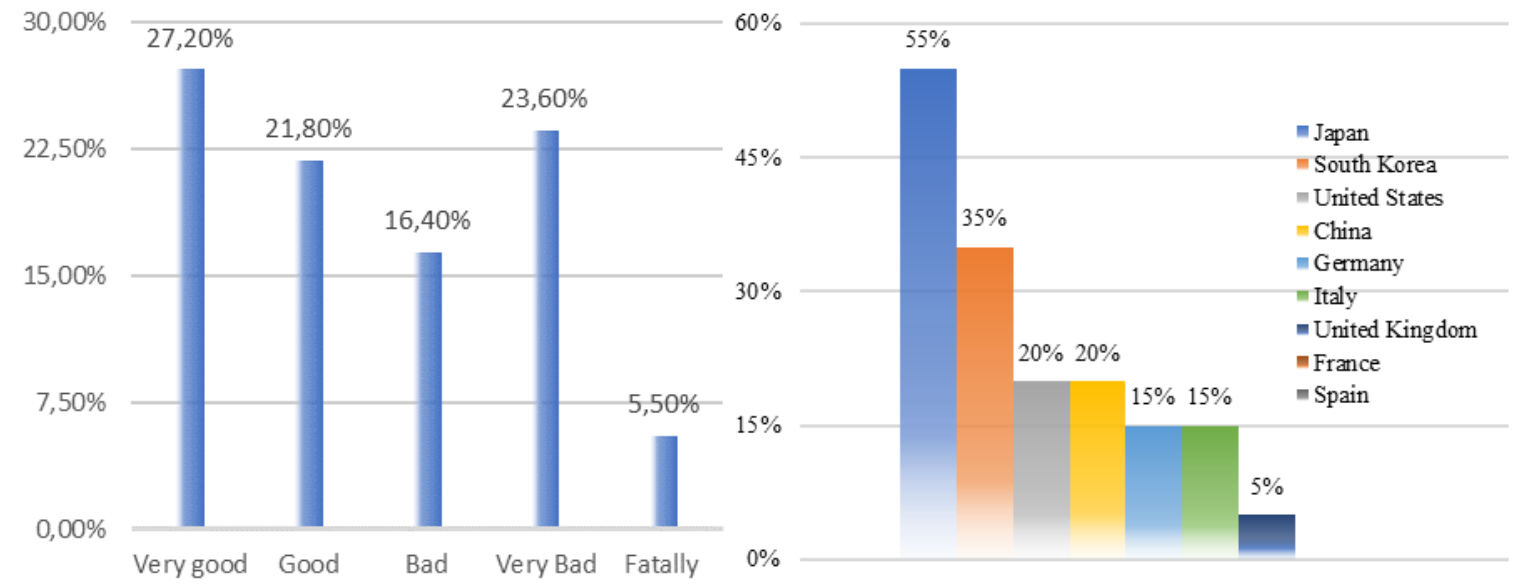

Figure 1. Impact of the COVID-19 pandemic on FinTech

Figure 2. Increase in the average weekly use of financial companies in Poland in 2020. applications during the COVID-19 pandemic in selected countries from 29 December 2019 to 1 March 2020

Source: statista.com, 2020. (Android phones only). Source: statista.com, 2020

The SARS-COV-2 pandemic is changing the way many financial institutions and fintech companies operate. Consumer behaviour is changing and the old risk assessment models no longer work. Banks are responding to the crisis related to the COVID-19 pandemic with new technologies (Ozili 2020; Wójcik \& Ioannou 2020, Solarz\&Waliszewski 2020). Mobile applications and alternative payment methods (also using biometric technology) are gaining popularity. Analysis of the instant payments market via Blue Media (2020) indicates that during the pandemic the amount of fast internet payments rose from $41 \%$ to $48 \%$, card payments from $32 \%$ to $39 \%$, with a noticeably growing interest in BLIK transactions from $24 \%$ to $33 \%$. The coronavirus pandemic resulted in a clear reversal of cash on delivery (from $46 \%$ to $24 \%$ ), automatic bank transfers (from $43 \%$ to $34 \%$ ) and cash upon receipt (from 16\% to $9 \%$ ). This relentless buzz of consumer activity on the mobile payments market conveyed no financial benefits upon the fintech industry. Due to the crisis caused by the coronavirus pandemic in the first quarter, investors interested in the fintech industry began to withdraw (Fintek 2020). On the other hand, market data on the continuation of cooperation between the fintech industry and banks show that almost 49\% of companies assessed that the pandemic has had a positive impact on their operations in 2020 (Fig. 2).

According to the data, the average weekly use of fintech applications in Japan increased by 55\%, which coincides with the onset of the COVID-19 pandemic. In contrast, in Spain, France, there was no increase in the average weekly time spent by users remotely managing their finances.

\section{Methodology}

The first study of PFM application users in Poland was nationwide and conducted on a group of $N=301$ people, 288 of whom admitted using applications that assist budget management, while 13 people did not use such applications. The questionnaire was made available on financial portals, including Bankier.pl and financial blogs. Among those who did not use the application, there was an even distribution in terms of sex and age, while the majority were working people with higher education, usually living in larger towns, from high income households of 2-3 persons. 


\section{ENTREPRENEURSHIP AND SUSTAINABILITY ISSUES}

ISSN 2345-0282 (online) http://jssidoi.org/jesi/

2021 Volume 8 Number 3 (March)

http://doi.org/10.9770/jesi.2021.8.3(42)

Make your research more visible, join the Twitter account of ENTREPRENEURSHIP AND SUSTAINABILITY ISSUES: @Entrepr69728810

The study group mainly consisted of men (66.67\% of the respondents), and people aged 26-35 (42.36\%). People with higher education accounted for $74.65 \%$ of the study group, and in terms of employment, most people work (79.44\%).

Table 3. Characteristics of the studied group in terms of sex, age, education and professional situation

\begin{tabular}{|c|c|c|c|c|c|}
\hline & & \multicolumn{2}{|c|}{ Does not use an application } & \multicolumn{2}{|c|}{ Application users } \\
\hline & & $N$ & $\%$ & $N$ & $\%$ \\
\hline \multirow[t]{2}{*}{ Sex } & Women & 7 & $53,85 \%$ & 96 & $33,33 \%$ \\
\hline & Men & 6 & $46,15 \%$ & 192 & $66,67 \%$ \\
\hline \multirow[t]{4}{*}{ Age } & $19-25$ & 2 & $15,38 \%$ & 78 & $27,08 \%$ \\
\hline & $26-35$ & 4 & $30,77 \%$ & 122 & $42,36 \%$ \\
\hline & $36-50$ & 4 & $30,77 \%$ & 84 & $29,17 \%$ \\
\hline & Over 50 & 3 & $23,08 \%$ & 4 & $1,39 \%$ \\
\hline \multirow[t]{2}{*}{ Education } & Secondary & 2 & $15,38 \%$ & 73 & $25,35 \%$ \\
\hline & Higher & 11 & $84,62 \%$ & 215 & $74,65 \%$ \\
\hline \multirow[t]{4}{*}{ Professional situation } & Student & 1 & $8,33 \%$ & 50 & $17,42 \%$ \\
\hline & Working & 11 & $91,67 \%$ & 228 & $79,44 \%$ \\
\hline & Retired & 0 & $0,00 \%$ & 1 & $0,35 \%$ \\
\hline & Unemployed & 0 & $0,00 \%$ & 8 & $2,79 \%$ \\
\hline
\end{tabular}

Note: $N$ - number, \% percentage

Most respondents live in cities with over 500,000 inhabitants (41.61\%), usually in households of 2-4 persons and with a high per capita income.

Table 4. Characteristics of the studied group in terms of place of residence, number of people in the household and income

\begin{tabular}{|c|c|c|c|c|c|}
\hline & & \multicolumn{2}{|c|}{$\begin{array}{l}\text { Does not use an } \\
\text { application }\end{array}$} & \multicolumn{2}{|c|}{ Application users } \\
\hline & & $N$ & $\%$ & $N$ & $\%$ \\
\hline \multirow{5}{*}{$\begin{array}{l}\text { Place of } \\
\text { residence }\end{array}$} & Village & 1 & $7,69 \%$ & 50 & $17,48 \%$ \\
\hline & Town below 50,000 residents & 2 & $15,38 \%$ & 46 & $16,08 \%$ \\
\hline & Town between 50,000 and 150,000 residents & 2 & $15,38 \%$ & 25 & $8,74 \%$ \\
\hline & City between 150,000 and 500,000 residents & 7 & $53,85 \%$ & 46 & $16,08 \%$ \\
\hline & City above 500,000 residents & 1 & $7,69 \%$ & 119 & $41,61 \%$ \\
\hline \multirow{5}{*}{$\begin{array}{l}\text { Number of } \\
\text { people } \\
\text { in the } \\
\text { household }\end{array}$} & 1 & 2 & $15,38 \%$ & 52 & $18,12 \%$ \\
\hline & 2 & 4 & $30,77 \%$ & 73 & $25,44 \%$ \\
\hline & 3 & 4 & $30,77 \%$ & 60 & $20,91 \%$ \\
\hline & 4 & 2 & $15,38 \%$ & 73 & $25,44 \%$ \\
\hline & 5 or more & 1 & $7,69 \%$ & 29 & $10,10 \%$ \\
\hline \multirow{6}{*}{$\begin{array}{l}\text { Average per } \\
\text { capita } \\
\text { income } \\
\text { (net) in the } \\
\text { household }\end{array}$} & Less than $1000 \mathrm{zt}$ & 0 & $0,00 \%$ & 9 & $3,23 \%$ \\
\hline & $1001-2000 \mathrm{zl}$ & 0 & $0,00 \%$ & 33 & $11,46 \%$ \\
\hline & $2001-3000 \mathrm{zl}$ & 4 & $30,77 \%$ & 56 & $19,44 \%$ \\
\hline & $3001-4000 \mathrm{zł}$ & 3 & $23,08 \%$ & 66 & $22,92 \%$ \\
\hline & $4001-5000 \mathrm{zł}$ & 2 & $15,38 \%$ & 35 & $12,15 \%$ \\
\hline & $5001 \mathrm{zł}$ or more & 4 & $30,77 \%$ & 80 & $27,78 \%$ \\
\hline
\end{tabular}

Note: $N$ - number, \%-percentage

The following research hypotheses were formulated:

H1: Gender would be statistically significantly associated with the assessment of application errors (more often noticed by women), the probability of giving a recommendation (more often recommended by women) and the assessment of how the application impacts budget management during self-isolation (mainly men).

H2: the age of the respondents would be statistically significantly associated with the likelihood of recommending the application to a friend, with the applications being recommended most often by people over 50, and least often by those aged 19-25. 
H3: place of residence would be statistically significantly associated with the evaluation of how well the application is organised, willingness to use it, and satisfaction with its use.

H4: the level of per capita household income would be statistically significantly related to the assessment of transparency and organisation of the application, satisfaction with its use and willingness to recommend it.

H5: higher education would be linked with more frequent use of the mobile application. Also, people with higher education would rate the transparency and organisation of the application higher, along with its userfriendliness.

H6: the type of application used would be statistically significantly associated with the assessment of how complicated the application is to install, its organisation, satisfaction with its use and willingness to recommend it.

The following statistical methods were used to analyse the results obtained: Pearson's Chi-squared test, and Cramer's $\mathrm{V}$ to test the strength of the relationship.

\section{Results}

Most of the respondents used non-banking applications (87.50\%). The most frequently mentioned were Kontomierz (15.28\%), YNAB (15.28\%), Spreadsheet (9.38\%), 1Money (6.94\%) and Family Finance Tracker $(6.60 \%)$.

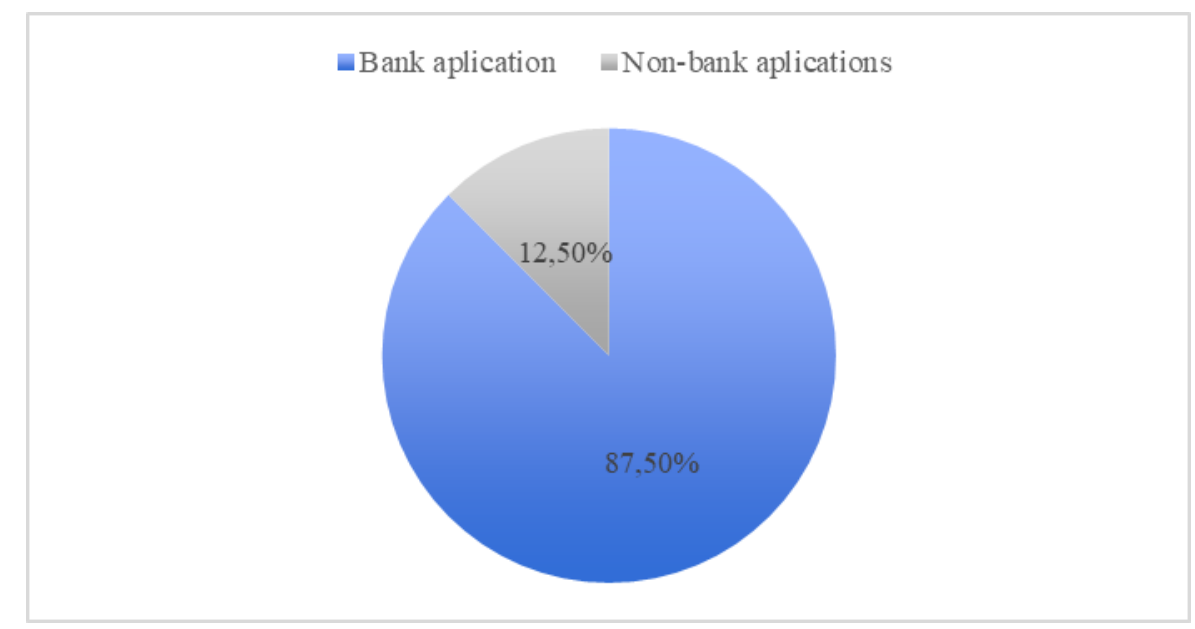

Figure 3. Type of applications used.

Source: own elaboration.

The main mentioned benefit of using an application was control over expenses (91.01\%), followed by developing the habit of saving (71.53\%), supporting financial decisions $(55.21 \%)$ and financial security through ongoing control of the bank balance.

In terms of shortcomings, the respondents mentioned the application's inability to make transfers and integrate with their bank, to establish sub-budgets, to scan documents, as well as the lack of exchange rates. 
Make your research more visible, join the Twitter account of ENTREPRENEURSHIP AND SUSTAINABILITY ISSUES: @Entrepr69728810

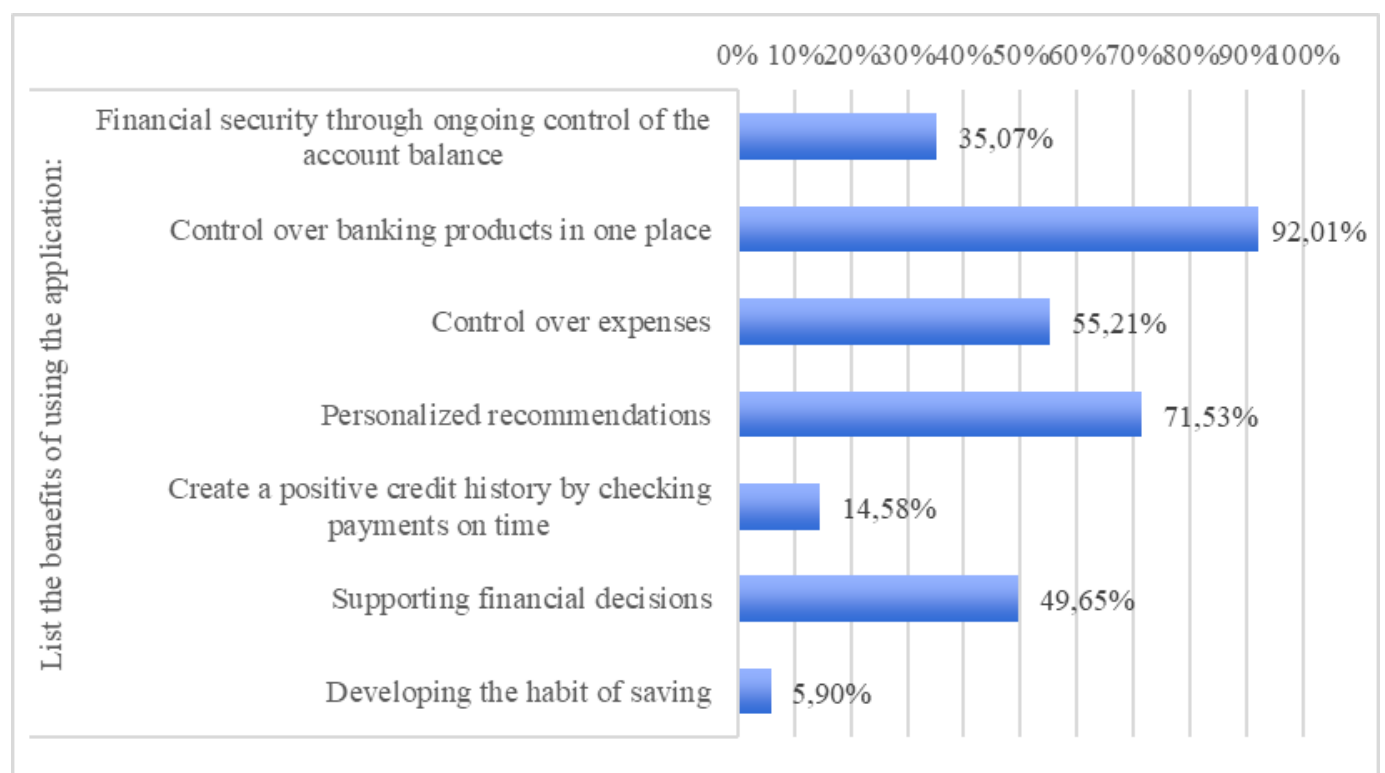

Figure 4. Evaluation of the benefits to be gained from using an application. Source: own elaboration.

The respondents usually believed that the application helped them manage their finances in a context of selfisolation, quarantine and remote work.

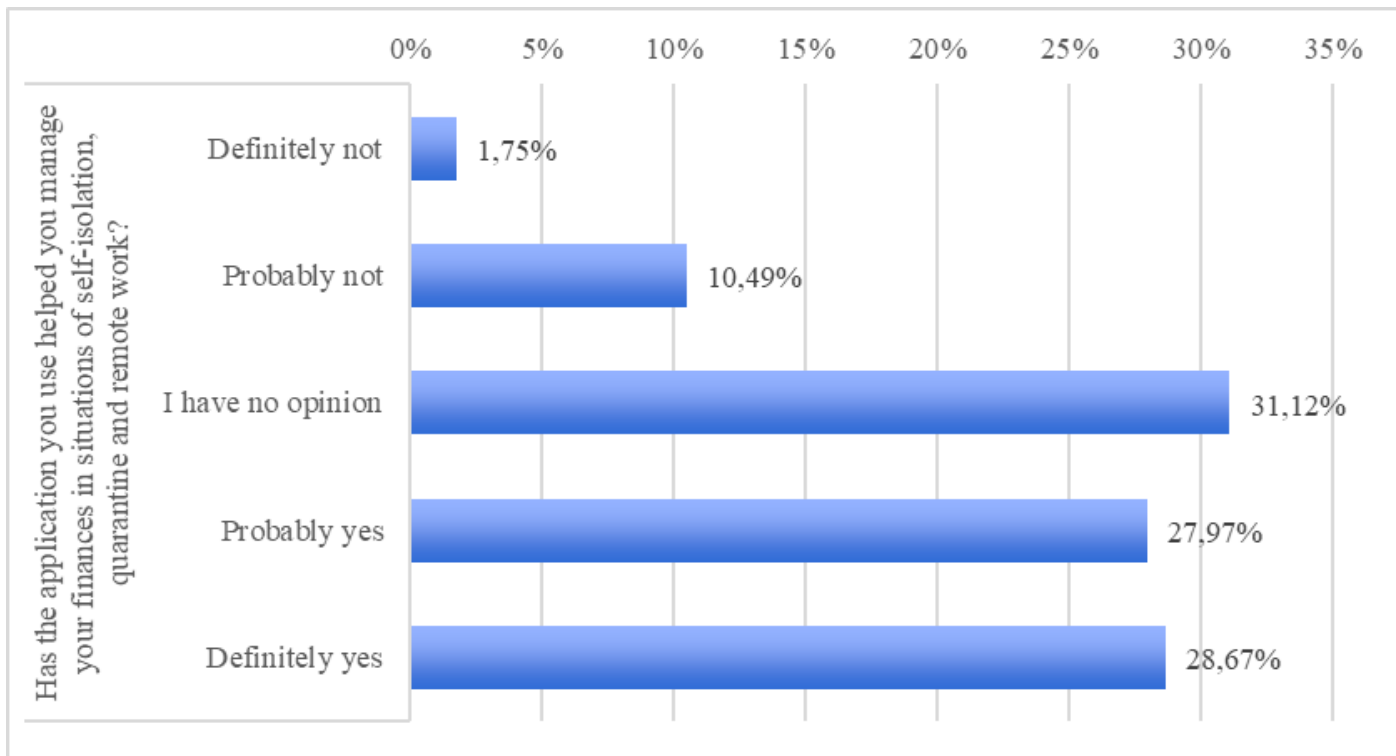

Figure 5. Using applications in times of self-isolation. Source: own elaboration.

According to the respondents, when it came to a pandemic situation, current settlements and payments (47.80\%), followed by sending scanned documents $(29.67 \%)$ and consultant's advice $(28.02 \%)$ were all areas that needed to be upgraded and better matched to user requirements. 
Make your research more visible, join the Twitter account of ENTREPRENEURSHIP AND SUSTAINABILITY ISSUES: @Entrepr69728810

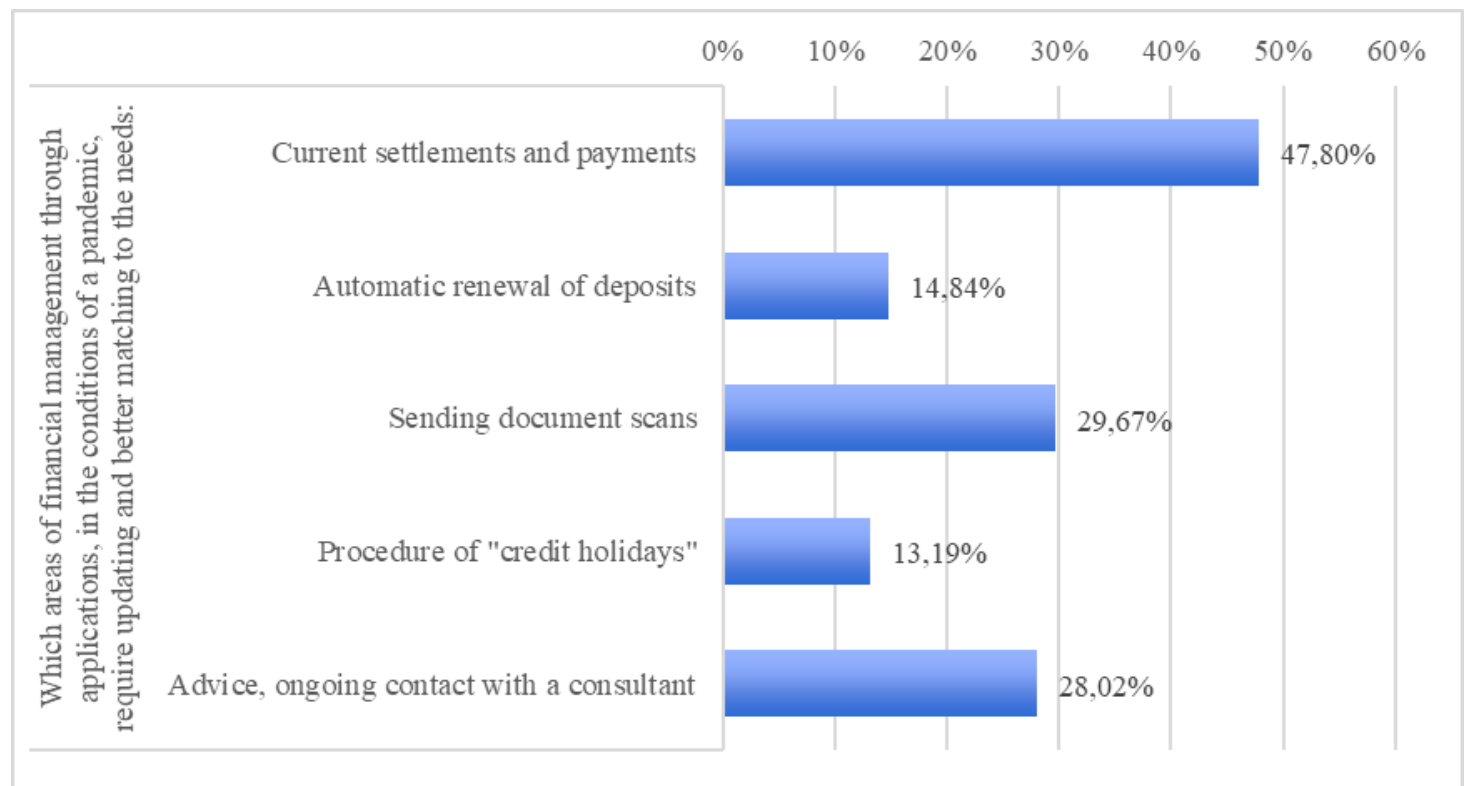

Figure 6. Evaluation of the possibility to improve applications. Source: own elaboration.

The Covid-19 pandemic most often affected the respondents by cutting back their income (32.99\%) and reducing their savings (25.69\%). $17.71 \%$ of people declared that the pandemic had had no impact on their home budget.

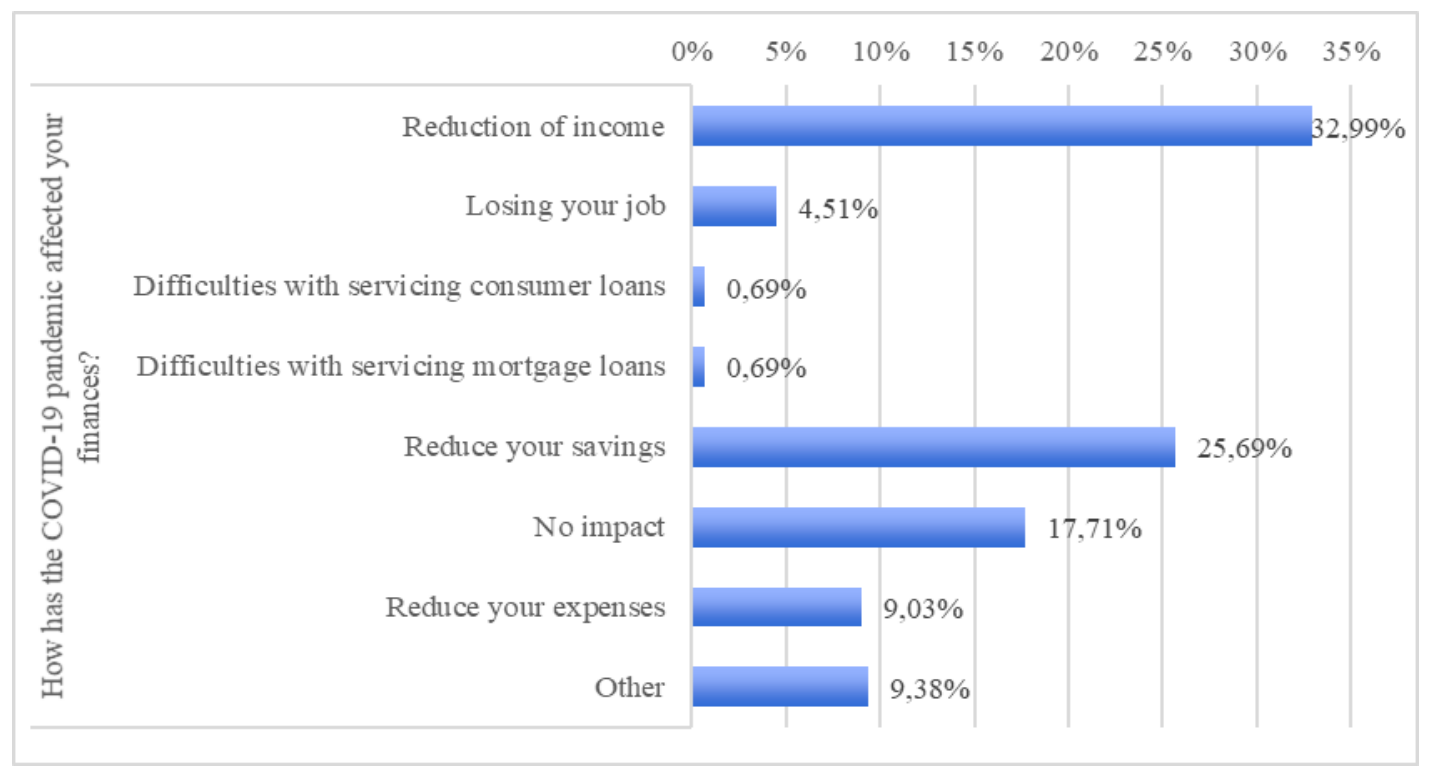

Figure 7. Impact of the pandemic on finances.

Source: own elaboration.

Further, the aim of the study was to determine, inter alia, whether and to what extent sociodemographic factors were related to how a home budget management application was evaluated. For this purpose, a series of analyses was performed using Chi-squared tests. 


\section{ENTREPRENEURSHIP AND SUSTAINABILITY ISSUES}

ISSN 2345-0282 (online) http://jssidoi.org/jesi/

2021 Volume 8 Number 3 (March)

http://doi.org/10.9770/jesi.2021.8.3(42)

Make your research more visible, join the Twitter account of ENTREPRENEURSHIP AND SUSTAINABILITY ISSUES: @Entrepr69728810

Table 5. Results of Chi-squared test analyses of the relationship between how home budget management applications are rated and gender

\begin{tabular}{|c|c|c|c|c|}
\hline Sex & $\chi^{2}$ & $d f$ & $p$ & $V$ \\
\hline How can you use the application? & 1,43 & 2 & 0,489 & 0,07 \\
\hline How complicated was it to install? & 3,91 & 3 & 0,271 & 0,13 \\
\hline The application you use is transparent: & 4,79 & 5 & 0,442 & 0,13 \\
\hline The application you use is organised: & 9,24 & 4 & 0,055 & 0,18 \\
\hline The application you use is user-friendly: & 4,02 & 4 & 0,404 & 0,12 \\
\hline Is the application intuitive and the functions easy to remember? & 4,47 & 4 & 0,347 & 0,13 \\
\hline Does the application have any flaws? & 8,39 & 2 & $\mathbf{0 , 0 1 5}$ & $\mathbf{0 , 1 7}$ \\
\hline Rate your satisfaction with the application. & 11,59 & 8 & 0,171 & 0,20 \\
\hline How likely are you to recommend the application to a friend? & 21,59 & 9 & $\mathbf{0 , 0 1 0}$ & $\mathbf{0 , 2 7}$ \\
\hline $\begin{array}{l}\text { Did the application you use help you manage your finances during self-isolation, quarantine or remote } \\
\text { work? }\end{array}$ & 11,71 & 4 & $\mathbf{0 , 0 2 0}$ & $\mathbf{0 , 2 0}$ \\
\hline
\end{tabular}

Notes: $\chi^{2-C h i-s q u a r e d ~ s t a t i s t i c s, ~} d$ - number of degrees of freedom, $p$ - level of statistical significance, $V$ - strength of the Cramer's $V$ relationship

The first series of Chi-squared analyses indicated that in the study group, gender was statistically significantly linked with the evaluation of application flaws $\chi^{2}(2)=8.39 ; p<0.05 ; V=0.17$, the likelihood of recommending it $\chi^{2}(9)=21.59 ; p<0.05 ; V=0.27$ and how the impact of the application on budget management in the situation of self-isolation was assessed $\chi 2(4)=11.71 ; p<0.05 ; V=0.20$.

In the study group, women $(9.38 \%)$ noticed errors in the budget management application demonstrably more often than men $(7.89 \%)$. Women also expressed that they would be less willing to recommend the application to their friends, scoring an average of $M=8.05$ on a $1-10$ scale, while men scored $M=8.43$. Men, on the other hand, were more often of the opinion that an application helped them manage their finances in the context of selfisolation, quarantine and remote work. However, these relationships were not strong.

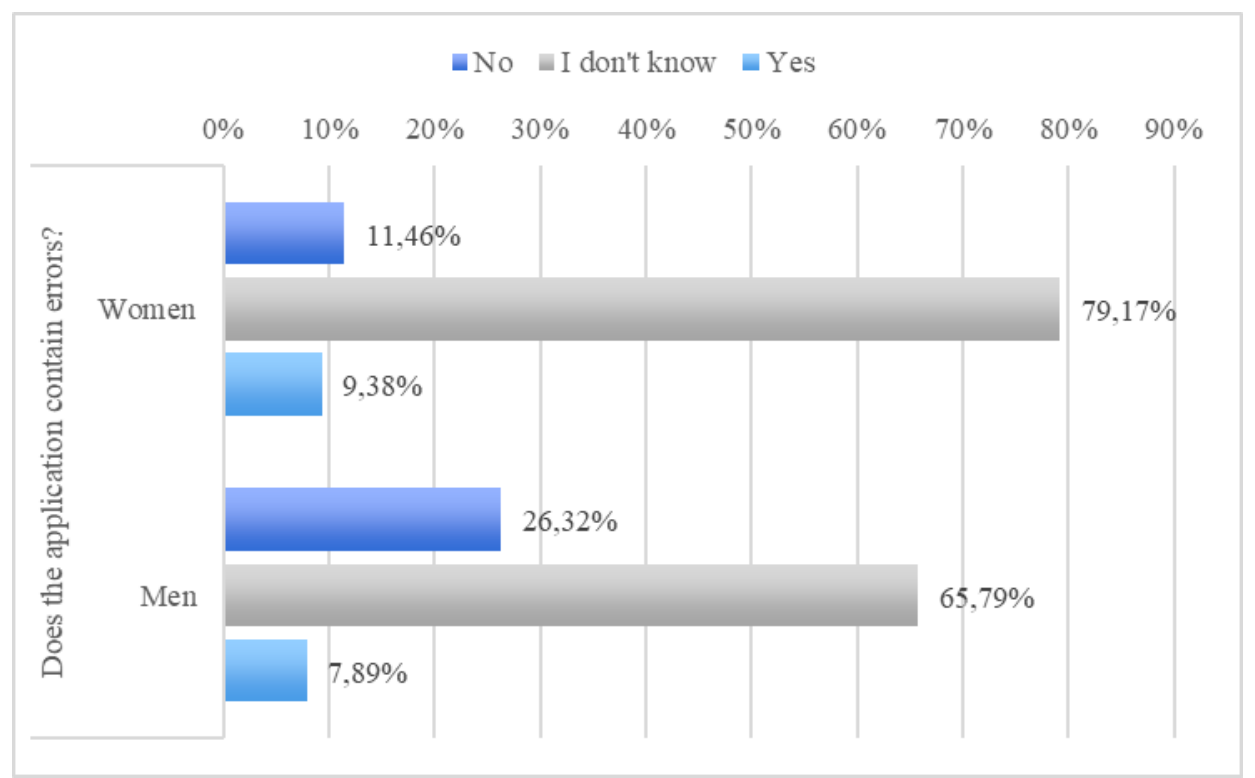

Figure 8. The relationship between the evaluation of flaws in the application and gender. Source: own elaboration. 


\section{ENTREPRENEURSHIP AND SUSTAINABILITY ISSUES}

ISSN 2345-0282 (online) http://jssidoi.org/jesi/

2021 Volume 8 Number 3 (March)

http://doi.org/10.9770/jesi.2021.8.3(42)

Make your research more visible, join the Twitter account of ENTREPRENEURSHIP AND SUSTAINABILITY ISSUES: @Entrepr69728810

The next Chi-squared analysis examined the relationship between the assessment of home budget management applications and age.

Table 6. Results of Chi-squared analyses of the relationship between the assessment of home budget management applications and age

\begin{tabular}{|c|c|c|c|c|}
\hline Age & $\chi^{2}$ & $d f$ & $p$ & $V$ \\
\hline How can you use the application? & 11,23 & 6 & 0,082 & 0,14 \\
\hline How complicated was it to install? & 9,65 & 9 & 0,379 & 0,11 \\
\hline The application you use is transparent: & 19,86 & 15 & 0,178 & 0,15 \\
\hline The application you use is organised: & 20,22 & 12 & 0,063 & 0,15 \\
\hline The application you use is user-friendly: & 8,38 & 12 & 0,755 & 0,10 \\
\hline Is the application intuitive and the functions easy to remember? & 11,87 & 12 & 0,456 & 0,12 \\
\hline Does the application have any flaws? & 11,93 & 6 & 0,064 & 0,14 \\
\hline Rate your satisfaction with the application. & 29,13 & 24 & 0,215 & 0,18 \\
\hline How likely are you to recommend the application to a friend? & 40,52 & 27 & 0,046 & $\mathbf{0 , 2 2}$ \\
\hline $\begin{array}{c}\text { Did the application you use help you manage your finances during self-isolation, quarantine or } \\
\text { remote work? }\end{array}$ & 12,98 & 12 & 0,371 & 0,12 \\
\hline
\end{tabular}

Notes: $\chi^{2-C h i-s q u a r e d ~ s t a t i s t i c s, ~} d f$ - number of degrees of freedom, $p$ - level of statistical significance, $V$ - strength of the Cramer's $V$ relationship

It was only demonstrated that the age of the respondents was statistically significantly associated with the likelihood of recommending the application to a friend $\chi^{2}(27)=40.52 ; p<0.05 ; V=0.22$. The highest probability of recommending the application to friends was expressed by people aged over $50 M=9.00$ and the lowest by people aged 19-25 $M=7.92$.

Table 7. Results of Chi-squared analyses for the relationship between how high home budget management applications were rated and education

\begin{tabular}{|c|c|c|c|c|}
\hline Education & $\chi^{2}$ & $d f$ & $p$ & $V$ \\
\hline How can you use the application? & 16,22 & 2 & $\mathbf{0 , 0 0 0}$ & $\mathbf{0 , 2 4}$ \\
\hline How complicated was it to install? & 2,71 & 3 & 0,439 & 0,10 \\
\hline The application you use is transparent: & 25,52 & 5 & $\mathbf{0 , 0 0 0}$ & $\mathbf{0 , 3 0}$ \\
\hline The application you use is organised: & 17,25 & 4 & 0,002 & $\mathbf{0 , 2 5}$ \\
\hline The application you use is user-friendly: & 11,81 & 4 & $\mathbf{0 , 0 1 9}$ & $\mathbf{0 , 2 0}$ \\
\hline Is the application intuitive and the functions easy to remember? & 12,16 & 4 & $\mathbf{0 , 0 1 6}$ & $\mathbf{0 , 2 1}$ \\
\hline Does the application have any flaws? & 3,97 & 2 & 0,138 & 0,12 \\
\hline Rate your satisfaction with the application. & 17,03 & 8 & $\mathbf{0 , 0 3 0}$ & $\mathbf{0 , 2 4}$ \\
\hline How likely are you to recommend the application to a friend? & $\mathbf{2 7 , 8 0}$ & 9 & 0,001 & $\mathbf{0 , 3 1}$ \\
\hline $\begin{array}{c}\text { Did the application you use help you manage your finances during self-isolation, quarantine or } \\
\text { remote work? }\end{array}$ & 12,33 & 4 & $\mathbf{0 , 0 1 5}$ & $\mathbf{0 , 2 1}$ \\
\hline
\end{tabular}

Notes: $\chi 2$ - Chi-squared statistics, $d f$ - number of degrees of freedom, $p$-level of statistical significance, $V$ - strength of the Cramer's $V$ relationship

A series of Chi-squared analyses yielded a number of statistically significant results for the relationship between how high home budget management applications are rated and education. The only indication was that education is not linked with how the complexity of the software installation is evaluated $\chi^{2}(3)=2.71 ; p=0.439 ; V=0.10$ and with the assessment of flaws in the application $\chi^{2}(2)=3.97 ; p=0.138 ; V=0.12$.

Among those with higher education, a greater percentage of respondents only used a mobile application (42.93\%), and these people also rated the application's transparency, organisation and user-friendliness higher. 


\section{ENTREPRENEURSHIP AND SUSTAINABILITY ISSUES}

ISSN 2345-0282 (online) http://jssidoi.org/jesi/

2021 Volume 8 Number 3 (March)

http://doi.org/10.9770/jesi.2021.8.3(42)

Make your research more visible, join the Twitter account of ENTREPRENEURSHIP AND SUSTAINABILITY ISSUES: @ Entrepr69728810

People with higher education were more often of the conviction that the application was definitely intuitive (47.44\%) and rated their level of satisfaction with the application higher ( $M=8.54$ points vs $M=8.06$ points).

People with higher education were also more likely to recommend the application to their friends $(M=8.49$ points vs $M=7.74$ points). Such people also tended to think that the application helped them manage their finances during self-isolation, quarantine and remote work. Level of education was most strongly associated with the desire to recommend the application to friends.

Table 8. Results of Chi-squared analyses for the relationship between the assessment of home budget management application and the

\begin{tabular}{|c|c|c|c|c|}
\hline Place of residence & $\chi^{2}$ & $d f$ & $p$ & $V$ \\
\hline How can you use the application? & 8,11 & 8 & 0,423 & 0,12 \\
\hline How complicated was it to install? & 15,24 & 12 & 0,229 & 0,13 \\
\hline The application you use is transparent: & 31,18 & 20 & 0,053 & 0,17 \\
\hline The application you use is organised: & 26,91 & 16 & $\mathbf{0 , 0 4 3}$ & $\mathbf{0 , 1 5}$ \\
\hline The application you use is user-friendly: & 30,78 & 16 & $\mathbf{0 , 0 1 4}$ & 0,16 \\
\hline Is the application intuitive and the functions easy to remember? & 14,31 & 16 & 0,576 & 0,11 \\
\hline Does the application have any flaws? & 9,05 & 8 & 0,338 & 0,13 \\
\hline Rate your satisfaction with the application. & 64,87 & 32 & 0,001 & $\mathbf{0 , 2 4}$ \\
\hline How likely are you to recommend the application to a friend? & 41,98 & 36 & 0,228 & 0,19 \\
\hline $\begin{array}{c}\text { Did the application you use help you } \\
\text { manage your finances during self-isolation, quarantine } \\
\text { or remote work? }\end{array}$ & 25,79 & 16 & 0,057 & 0,15 \\
\hline
\end{tabular}

Notes: $\chi 2$ - Chi-squared statistics, df- number of degrees of freedom, $p$-level of statistical significance, $V$ - strength of the Cramer's $V$ relationship

Another series of Chi-squared analyses showed that the place of residence was statistically significantly linked with the evaluation of the application's organisation $\chi^{2}(16)=26.91 ; p<0.05 ; V=0.15$, user-friendliness $\chi^{2}$ (16) $=30.78 ; \mathrm{p}<0.05 ; V=0.16$, and satisfaction with the application $\chi 2(32)=64.87 ; p<0.01 ; V=0.24$.

The inhabitants of cities with 150,000-500,000 residents rated organisation and user-friendliness the highest while village residents gave these aspects the lowest rating. Also, the inhabitants of cities with 150,000-500,000 residents were the most satisfied with the application. Place of residence was most strongly associated with satisfaction.

Table 9. Results of Chi-squared analyses for the relationship between the assessment of home budget management applications and household size

\begin{tabular}{|c|c|c|c|c|}
\hline Household size & $\chi^{2}$ & $d f$ & $p$ & $V$ \\
\hline How can you use the application? & 8,97 & 8 & 0,345 & 0,13 \\
\hline How complicated was it to install? & 20,68 & 12 & 0,055 & 0,16 \\
\hline The application you use is transparent: & 13,36 & 20 & 0,862 & 0,11 \\
\hline The application you use is organised: & 21,19 & 16 & 0,171 & 0,14 \\
\hline The application you use is user-friendly: & 20,56 & 16 & 0,196 & 0,13 \\
\hline Is the application intuitive and the functions easy to remember? & 12,33 & 16 & 0,721 & 0,11 \\
\hline Does the application have any flaws? & 7,76 & 8 & 0,457 & 0,12 \\
\hline Rate your satisfaction with the application. & 25,55 & 32 & 0,783 & 0,15 \\
\hline How likely are you to recommend the application to a friend? & 51,63 & 36 & 0,054 & 0,21 \\
\hline $\begin{array}{l}\text { Did the application you use help you } \\
\text { manage your finances during self-isolation, quarantine } \\
\text { or remote work? }\end{array}$ & 17,46 & 16 & 0,356 & 0,12 \\
\hline
\end{tabular}

Notes: $\chi 2$ - Chi-squared statistics, $d$ - number of degrees of freedom, $p$ - level of statistical significance, $V$ - strength of the Cramer's $V$ relationship 


\section{ENTREPRENEURSHIP AND SUSTAINABILITY ISSUES}

ISSN 2345-0282 (online) http://jssidoi.org/jesi/

2021 Volume 8 Number 3 (March)

http://doi.org/10.9770/jesi.2021.8.3(42)

Make your research more visible, join the Twitter account of ENTREPRENEURSHIP AND SUSTAINABILITY ISSUES: @Entrepr69728810

There was no indication that the size of the respondents' household was statistically significantly associated with how they rated home budget management applications.

Similarly, Table 10 below presents the results of Chi-squared analyses for the relationship between the assessment of the home budget management application and income.

Table 10. Results of Chi-squared analyses for the relationship between the assessment of home budget management applications and income

\begin{tabular}{|c|c|c|c|c|}
\hline Income & $\chi^{2}$ & $d f$ & $p$ & 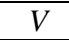 \\
\hline How can you use the application? & 12,71 & 10 & 0,241 & 0,15 \\
\hline How complicated was it to install? & 24,08 & 15 & 0,064 & 0,17 \\
\hline The application you use is transparent: & 40,34 & 25 & $\mathbf{0 , 0 2 7}$ & $\mathbf{0 , 1 7}$ \\
\hline The application you use is organised: & 56,68 & 20 & $\mathbf{0 , 0 0 0}$ & $\mathbf{0 , 2 3}$ \\
\hline The application you use is user-friendly: & 27,89 & 20 & 0,112 & 0,16 \\
\hline Is the application intuitive and the functions easy to remember? & 20,28 & 20 & 0,440 & 0,14 \\
\hline Does the application have any flaws? & 14,60 & 10 & 0,147 & 0,16 \\
\hline Rate your satisfaction with the application. & 74,32 & 40 & $\mathbf{0 , 0 0 1}$ & $\mathbf{0 , 2 3}$ \\
\hline How likely are you to recommend the application to a friend? & 66,97 & 45 & $\mathbf{0 , 0 1 8}$ & $\mathbf{0 , 2 2}$ \\
\hline $\begin{array}{l}\text { Did the application you use help you } \\
\text { manage your finances during self-isolation, quarantine } \\
\text { or remote work? }\end{array}$ & 25,79 & 20 & 0,173 & 0,15 \\
\hline
\end{tabular}

Notes: $\chi 2$-Chi-squared statistics, $d f$-number of degrees of freedom, $p$-level of statistical significance, $V$ - strength of the Cramer's $V$ relationship

Chi-squared test results demonstrated that the level of per capita household income was statistically significantly linked with the transparency rating $\chi^{2}(25)=40.34 ; p<0.05 ; V=0.17$, application organisation $\chi^{2}(20)=56.68 ; p$ $<0.001 ; V=0.23$, satisfaction with the application $\chi^{2}(40)=74.32 ; p<0.01 ; V=0.23$ and the willingness to recommend the application $\chi^{2}(45)=66.97 ; p<0.05 ; V=0.22$.

The greater the respondents' per capita household income, the more favourable was their assessment of the application's transparency and organisation, the higher their satisfaction with the application and the greater the likelihood of recommending it to friends. The next stage of the study was to determine whether the assessment of the home budget management application was related to different ways of using the application and the type of application used (banking/non-banking). For this purpose, a series of Chi-squared analyses was also performed. The following table 11 presents the results of the Chi-squared tests for the relationship between the assessment of home budget management applications and the way the application is used.

Table 11. Results of Chi-squared analyses for the relationship between the assessment of home budget management applications and the way the application is used

\begin{tabular}{|c|c|c|c|c|}
\hline How can you use the application? & $\chi^{2}$ & $d f$ & $p$ & $V$ \\
\hline How complicated was it to install? & 22,19 & 6 & $\mathbf{0 , 0 0 1}$ & $\mathbf{0 , 2 0}$ \\
\hline The application you use is transparent: & 39,29 & 10 & $\mathbf{0 , 0 0 0}$ & $\mathbf{0 , 2 7}$ \\
\hline The application you use is organised: & 12,96 & 8 & 0,113 & 0,15 \\
\hline The application you use is user-friendly: & $\mathbf{1 9 , 4 1}$ & 8 & $\mathbf{0 , 0 1 3}$ & $\mathbf{0 , 1 8}$ \\
\hline Is the application intuitive and the functions easy to remember? & 30,74 & 8 & $\mathbf{0 , 0 0 0}$ & 0,24 \\
\hline Does the application have any flaws? & 5,79 & 4 & 0,215 & 0,10 \\
\hline Rate your satisfaction with the application. & 39,99 & 16 & 0,001 & $\mathbf{0 , 2 7}$ \\
\hline How likely are you to recommend the application to a friend? & $\mathbf{3 7 , 5 8}$ & 18 & 0,004 & 0,26 \\
\hline $\begin{array}{c}\text { Did the application you use help you } \\
\text { manage your finances during self-isolation, quarantine } \\
\text { or remote work? }\end{array}$ & 15,87 & 8 & 0,044 & $\mathbf{0 , 1 7}$ \\
\hline
\end{tabular}

Notes: $\chi 2$ - Chi-squared statistics, $d f$ - number of degrees of freedom, $p$ - level of statistical significance, $V$ - strength of the Cramer's $V$ relationship 


\section{ENTREPRENEURSHIP AND SUSTAINABILITY ISSUES}

ISSN 2345-0282 (online) http://jssidoi.org/jesi/

2021 Volume 8 Number 3 (March)

http://doi.org/10.9770/jesi.2021.8.3(42)

Make your research more visible, join the Twitter account of ENTREPRENEURSHIP AND SUSTAINABILITY ISSUES: @ Entrepr69728810

A series of Chi-squared analyses gave a number of statistically significant results for the relationship between the assessment of home budget management applications and the way the application is used. How the application is used was only demonstrated to be unrelated to the evaluation of the application's organisation $\chi^{2}(8)=12.96 ; p=$ $0.113 ; V=0.15$ and with the evaluation of application flaws $\chi^{2}(4)=5.79 ; p=0.215 ; V=0.10$.

People who only used the application via a website considered the software to be the most difficult to install, and these people also believed that the application was the least transparent and user-friendly. Furthermore, those who only used the application via a website were of the opinion that it was less intuitive and were the least satisfied with it. People using the application solely via a website were the least likely to recommend the application to their friends, and believed that the application helped them manage their budget during the pandemic the least.

Also, Chi-squared tests were used to analyse the relationship between the assessment of home budget management applications and the type of applications.

Table 12. Results of Chi-squared analyses for the relationship between the assessment of home budget management applications and the type of application

\begin{tabular}{|c|c|c|c|c|}
\hline Type of application & $\chi^{2}$ & $d f$ & $p$ & $V$ \\
\hline How can you use the application? & 4,62 & 2 & 0,099 & 0,13 \\
\hline How complicated was it to install? & 9,45 & 3 & $\mathbf{0 , 0 2 4}$ & $\mathbf{0 , 1 8}$ \\
\hline The application you use is transparent: & 9,16 & 5 & 0,103 & 0,18 \\
\hline The application you use is organised: & 14,63 & 4 & 0,006 & $\mathbf{0 , 2 3}$ \\
\hline The application you use is user-friendly: & 6,87 & 4 & 0,143 & 0,16 \\
\hline Is the application intuitive and the functions easy to remember? & 3,02 & 4 & 0,554 & 0,10 \\
\hline Does the application have any flaws? & 6,77 & 2 & $\mathbf{0 , 0 3 4}$ & $\mathbf{0 , 1 5}$ \\
\hline Rate your satisfaction with the application. & 17,01 & 8 & $\mathbf{0 , 0 3 0}$ & $\mathbf{0 , 1 4}$ \\
\hline How likely are you to recommend the application to a friend? & 19,77 & 9 & $\mathbf{0 , 0 1 9}$ & 0,26 \\
\hline $\begin{array}{l}\text { Did the application you use help you manage your finances during self-isolation, quarantine or remote } \\
\text { work? }\end{array}$ & 8,39 & 4 & 0,078 & 0,17 \\
\hline
\end{tabular}

Notes: $\chi 2$-Chi-squared statistics, $d f$-number of degrees of freedom, $p$-level of statistical significance, $V$ - strength of the Cramer's $V$ relationship

A further analysis conducted by using Chi-squared tests showed that the type of application used was statistically significantly related to the evaluation how easy the application is to install $\chi^{2}(3)=9.45 ; p<0.05 ; V=0.18$, with the assessment of its organisation $\chi^{2}(4)=14.63 ; p<0.01 ; V=0.23$, flaws $\chi^{2}(2)=6.77 ; p<0.05 ; V=0.15$, satisfaction with the application $\chi^{2}(8)=17.01 ; p<0.05 ; V=0.14$ and the willingness to recommend it $\chi^{2}(9)=$ $19.77 ; p<0.05 ; V=0.26$. People using a non-banking application more often considered that the software was easy to install and rated the organisation of the application higher. People using the banking application noticed flaws in the application more often, and satisfaction with using the application was rated higher by users of a nonbanking application $(M=8.45$ vs $M=8.25)$. People using a non-banking application were more likely to recommend a budget management application $(M=8.38$ vs $M=7.75)$.

\section{Discussion}

The study attempts to verify how popular and useful are applications supporting personal finance management in Poland. Low popularity of applications supporting the process of personal finance management reported in numerous market studies was a reason to conduct the first nationwide survey in Poland. The study showed that users more often use non-bank applications than financial managers offered by banks. High diversification of the market in terms of PFM applications gives a chance to potential users to choose a tool tailored to their needs. 


\section{ENTREPRENEURSHIP AND SUSTAINABILITY ISSUES}

ISSN 2345-0282 (online) http://jssidoi.org/jesi/

2021 Volume 8 Number 3 (March)

http://doi.org/10.9770/jesi.2021.8.3(42)

Make your research more visible, join the Twitter account of ENTREPRENEURSHIP AND SUSTAINABILITY ISSUES: @Entrepr69728810

Therefore, one should wonder why the offer of banking institutions is not attractive to current users? Lack of the previous extension of services in banking applications does not give a chance for full use of bank managers, among other things, through the lack of change in categorization of expenses and gaps in technology (import and export of data) and communication with the bank. However, the authors of the study point out that the pandemic period may influence the acceleration of technological measures and the following legal regulations in mobile banking. It should be noted that it is necessary to continue research work on the topic of individual functionalities of PFM applications, which may be a motivating factor for financial institutions to better adapt tools to the needs of customers. It is also worth considering consortium research on the subject.

\section{Conclusion}

The study showed that men and those in the 26-35 age group most often used home budget management applications during the pandemic and self-isolation. Women noticed flaws in budget management applications more often and were less likely to recommend an application to their friends. Men were more often of the opinion that the application they used helped them manage their finances during self-isolation, quarantine and remote work. There was no single relationship in the study group between evaluation of applications and age. Most of the people who use applications have higher education. These people also rated applications much higher, considered them clear and easy to use, and would be more likely to recommend them to their friends. It was also demonstrated that the respondents' place of residence and income were related to how applications were evaluated. Applications were rated best by city residents and those with high per capita household incomes.

Most of the respondents used applications in their mobile and website versions, or just the mobile version. However, the minority of people who only used an application in its website version rated it the worst and would be more reluctant to recommend it to their friends. These relationships were moderately strong. People using nonbanking applications also rated the application much better. Despite the differences described, most of the respondents conceded that the application helped them monitor their household budget during self-isolation and remote work. The respondents mentioned that applications had many advantages and only a handful of disadvantages.

The SARS-CoV-2 pandemic has cast light on gaps in remote customer service, such as the need for better adaptation to the requirements of making current settlements and payments, the inability to scan documents, and the lack of advice and ongoing contact with a consultant. The study conducted in the context of social isolation identified opportunities and threats for providers of financial management support services, especially in terms of the tools on offer. The assessment of PFM application usability gives room for them to be adapted to the changing needs of consumers. The issues raised require further, cognitive research. The conducted research confirmed research hypotheses H1-H6.

\section{References}

Abad-Segura, E., González-Zamar, M.D., López-Meneses, E., Vázquez-Cano, E. (2020). Financial Technology: Review of Trends, Approaches and Management, Mathematics, 8(6), 951. http://doi.org/10.3390/math8060951

Albertazzi, D. (2018). Rebuilding Personal Financial Management in 2018: What Banks Need to Know, Alite, https://aitegroup.com/report/rebuilding-personal-financial-management-2018-what-banks-need-know [accessed 19.10.2020].

Alebank.pl. (2013). Bank and Client: PFM in the West, https://alebank.pl/bank-i-klient-pfm-na-zachodzie/ [accessed 19.10.2020].

Alt, R., Beck, R., Smits, M.T. (2018). FinTech and the transformation of the financial industry, Electronic Market, 28 , pp. $235-243$. http://doi.org/10.1007/s12525-018-0310-9

Baker, T. \& Dellaert, B. (2017). Regulating Robo Advice Across the Financial Services Industry, University of Pennsylvania Carey Law School, Faculty Scholarship at Penn Law. 1740. 


\section{ENTREPRENEURSHIP AND SUSTAINABILITY ISSUES}

ISSN 2345-0282 (online) http://jssidoi.org/jesi/

2021 Volume 8 Number 3 (March)

http://doi.org/10.9770/jesi.2021.8.3(42)

Make your research more visible, join the Twitter account of ENTREPRENEURSHIP AND SUSTAINABILITY ISSUES: @Entrepr69728810

Barembruch, A. (2013). Retail Banking and modern tools to help manage personal finances, Management and Finance, 2, No. 1: pp. 34-46

Belanche, D., Casaló, L.V., \& Flavián, C. (2018). Artificial Intelligence in fintech: understanding robo-advisors adoption among customers, Industrial Management \& Data System, 119, 1411-1430. http://doi.org/10.1108/IMDS-08-2018-0368

Belanche, D., Casaló, L.V., Flavián, C. And Guinalíu, M. (2019): Reciprocity and commitment in online travel communities, Industrial Management \& Data Systems, 119, 2, 397-411. http://doi.org/10.1108/IMDS-03-2018-0098

Blue Media. (2020). Rośnie popularność płatności elektronicznych (Electronic payments are becoming more and more popular), https://bluemedia.pl/pressroom/informacje-prasowe/rosnie-popularnosc-platnosci-elektronicznych [accessed 19.10.2020].

Boon-Itt, S. (2015). Managing self-service technology services quality to enhance e-satisfaction, International Journal of Quality and Service Sciences, 7(4), 373-392. http://doi.org/10.1108/IJQSS-01-2015-0013

Djelassi, S., Diallo, M.F. \& Zielke, S. (2018): How self-service technology experience evaluation affect waiting time and customer satisfaction? A moderated mediation model. Decision Support Systems, Elsevier, 111, 38-47. http://doi.org/10.1016/j.dss.2018.04.004

E-Izby Raport. Izba Gospodarki Elektronicznej. (2017). Polish Wallet. Payments, budget, investments and savings, https://eizba.pl/cbw/raport-portfel-polaka/ [accessed: 15.10.2020].

EIOPA-BoS-20-002. (2020). Guidelines on outsourcing to cloud service provider, https://www.eiopa.europa.eu/sites/default/files/publications/eiopa guidelines/guidelines on outsourcing to cloud service providers cor_pl_0.pdf

EU Directive 2015/2366, Payment services (PSD2)

Farah, P., Macaulay, J., Ericsson, J. (2010). The next growth opportunity for banks how the post-crises financial needs of younger consumers will transform retail banking services, Survey Report, https://www.semanticscholar.org/paper [accessed 19.10.2020].

Financial Conduct Authority. (2020). Regulatory sandbox. Regulatory sandbox. https://www.fca.org.uk/firms/innovation/regulatory$\underline{\text { sandbox }}$

Fintek. (2020). Polish Fintech sector in the face of the SARS-COV-2 coronavirus pandemic, https://fintek.pl/wpcontent/uploads/2020/06/Polski-sektor-Fintech-w-obliczu-pandemii-koronawirusa-SARS-CoV-2.pdf [accessed 30.10.2020].

Gafrikova, V., Szczesny W., Odrzygóźdź Z. (2015). Online personal finance management applications, Information Systems in Managament, 4, 1, 39-52.

GSMA. (2019): State of the Industry Report on Mobile Money, Retrieved from https://www.gsma.com/sotir/wpcontent/uploads/2020/03/GSMA-State-of-the-Industry-Report-on-Mobile-Money-2019-Full-Report.pdf [accessed 02.11.2020].

Haikel-Elsabeh, M., Nouet, S. (2016). How Personal Finance Management Influences Consumers' Motivations and Behavior Regarding Online Banking Services, Communication Strategy, 103, 15.

Javaria, K., Masood, O., Garcia, F. (2020). Strategies to manage the risks faced by consumers in developing e-commerce. Insights into Regional Development, 2(4), 774-783. http://doi.org/10.9770/IRD.2020.2.4(4)

Jung, D., Dorner, V., Glaser, F., Morana, S. (2018): Robo-Advisory: Digitalization and Automation of Financial Advisory, Business \& Information Systems Engineering, 60, 81-86. http://doi.org/10.1007/s12599-018-0521-9

Jung, D., Glaser, F., Köpplin, W. (2019). Robo-Advisory: Opportunities and Risks for the Future of Financial Advisory in: V. Nissen (ed.), Advances in Consulting Research. Recent Findings and Practical Cases, Springer Nature Switzerland AG, $405-427$. http://doi.org/10.1007/978-3-319-95999-3

Marder, T. (2016). Fintech for the Consumer Market: an Overview, Consumer Compliance Outlook: pp. 4-20

Mastercard, Europejskie badanie nt. bankowości cyfrowej (European Digital Banking Survey), https://newsroom.mastercard.com/eu/pl/press-releases/badanie-mastercard-polacy-cenia-sobie-bankowosc-mobilna-i-online-zawygode-i-szybkosc-oczekuja-bezpieczenstwa/ [accessed: 15.10.2020]

Musiał, M. (2015). Application of personal finance management instruments in Polish households, Quarterly Journal of the Economic and Social College. Studies and Works, http://doi.org/10.33119/KKESSiP.2015.4.3.16

My Ing Survey. (2016). Poles' Payment Habits; Retrieved from: https://media.ing.pl/informacje-prasowe/926/pr/329427/finansecenniejsze-niz-zdrowie-ale-malo-o-nie-dbamy-badanie-moje-ing-zwyczaje-finansowe-polakow [access: 15.10.2020].

Nicoll, A. (2019). Millennials face \$1 trillion of debt, and want money management tools to help them manage their way out of it. But mobile-banking apps are lagging. Business Insider. Retrieved from: https://www.businessinsider.com/millennials-want-moneymanagement-features-in-mobile-banking-apps-2019-6?IR=T [accessed: 17.10.2020].

Nielsen, J. (2012). Usability 101: Introduction to Usability, Retrieved from https://www.nngroup.com/articles/usability-101-introductionto-usability/ [accessed: 27.05.2020].

OECD. (2018). G20/OECD INFE Policy Guidance. Digitalisation and Financial Literacy.

Omarini, A.E. (2018). Banks and Fintechs: How to develop a digital open banking approach for the bank's future, International Business Research, 11(9), 23-36. http://doi.org/10.5539/ibr.v11n9p23

Ozili, P.K. (2020). Financial Inclusion and Fintech during COVID-19 Crisis: Policy Solution, Available at SSRN: https://ssrn.com/abstract=3585662 or http://dx.doi.org/10.2139/ssrn.3585662

Parasuraman, A. (2000). Technology readiness index (Tri): a multiple-item scale to measure readiness to embrace new technologies, Journal of Service Research, 2(4), 307-320. http://doi.org/10.1177/109467050024001

RCS. (2012). Using technology to help manage finances, Retrieved from https://www.rcstechnology.com/ [accessed 10.10.2020]. 


\section{ENTREPRENEURSHIP AND SUSTAINABILITY ISSUES}

ISSN 2345-0282 (online) http://jssidoi.org/jesi/

2021 Volume 8 Number 3 (March)

http://doi.org/10.9770/jesi.2021.8.3(42)

Make your research more visible, join the Twitter account of ENTREPRENEURSHIP AND SUSTAINABILITY ISSUES: @ Entrepr69728810

Samsel, A. (2019). Planning as part of household budget management, Insurance hearings. Konsument na rynku ustug finansowych, 31 (1/2019), pp. 57-68.

Solarz, K., Waliszewski, K. (2020). Holistic Framework for COVID-19 Pandemic as Systemic Risk. European Research Studies Journal, Volume XXIII, Special Issue 2, 340-351. http://doi.org/10.35808/ersj/1827

Statista.com. (2020): https://www.statista.com [accessed 2.11.2020].

Thakor, A.V. (2020). Fintech and Banking. What do we know? Journal of Financial Intermediation, Elsevier, 41, 1-13, http://doi.org/10.1016/j.jfi.2019.100833

Uryniuk, J. (2012). The application helps to spend less, NBP a series of supplements under the economic education programme, Dziennik Gazeta Prawna.

Waliszewski, K., Warchlewska, A. (2020a). Socio-Demographic Factors Determining Expectation Experienced while Using Modern Technologies in Personal Financial Management (PFM and robo-advice): A Polish Case. European Research Studies Journal, Volume XXIII, Special Issue 2, 893-904, DOI: 10.35808/ersj/1904

Waliszewski, K., Warchlewska, A. (2020b). Who uses robo-advisors? The Polish case. European Research Studies Journal, Volume XXIII, Special Issue 1, 97-114. http://doi.org/10.35808/ersj/1748

Wójcik, D., Ioannou, S. (2020). COVID-19 and Finance: Market Developments So Far and Potential Impacts on the Financial Sector and Centres. Journal of Economic and Social Geography, 111(3) http://doi.org/10.1111/tesg.12434

Xiao, J., Tao, Ch. (2020). Consumer finance/household finance: the definition and scope, Chine Finance Review International, 1-25, http://doi.org/10.1108/CFRI-04-2020-0032

Xie, M. (2019). Development of Artificial Intelligence and Effects on Financial System, Journal of Physics. Conference Series, 1187, 032084, pp. 1-7. http://doi.org/10.1088/1742-6596/1187/3/03208

\section{Acknowledgement}

The project was financed within the Regional Initiative for Excellence programme of the Minister of Science and Higher Education of Poland, years 2019-2022, grant no. 004/RID/2018/19, financing 3,000,000 PLN.

Krzysztof WALISZEWSKI is Associate Professor in Poznań University of Economics and Business, Poland, at the Institute of Finance. His research focuses on the personal financial planning and management, financial intermediation, personal financial advice, fin-tech and robo-advice.

ORCID ID: 0000-0003-4239-5875

Anna WARCHLEWSKA is Assistant Professor in Poznań University of Economics and Business, Poland, at the Institute of Finance. Her research focuses on personal financial management, modern applications of mobile banking - PFM, financial education, financial exclusion.

ORCID ID: 000-0003-0142-7877

\footnotetext{
Copyright (C) 2021 by author(s) and VsI Entrepreneurship and Sustainability Center

This work is licensed under the Creative Commons Attribution International License (CC BY).

http://creativecommons.org/licenses/by/4.0/

cC (i) Open Access
} 